\title{
Comparison of efficacy of the intermittent pneumatic compression with various pressures in reducing the primary lower extremity venous lymphedema of menopausal patients
}

\section{Porównanie skuteczności sekwencyinego masażu uciskowego o różnym ciśnieniu w leczeniu pierwotnego obrzęku żylno-chłonnego kończyn dolnych u pacjentek w okresie menopauzalnym}

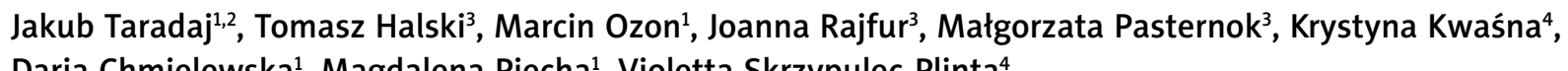
Daria Chmielewska1, Magdalena Piecha ${ }^{1}$, Violetta Skrzypulec-Plinta ${ }^{4}$

${ }^{1}$ Chair of Physiotherapy Basics, Academy of Physical Education, Katowice;

Head of Department: Jakub Taradaj, MD, PhD

${ }^{2}$ Department of Medical Biophysics, Medical University of Silesia, Katowice;

Head of Department: Prof. Andrzej Franek

${ }^{3}$ Institute of Physiotherapy, Public Higher Medical Professional School, Opole;

Head of Department: mgr Joanna Rajfur

${ }^{4}$ Department of Woman's Health Care, Medical University of Silesia, Katowice;

Head of Department: Prof. Violetta Skrzypulec-Plinta

Przegląd Menopauzalny 2013; 6: 472-477

\section{Summary}

Introduction: The primary lymphedema and chronic venous insufficiency are important medical problems in women during menopause. Intermittent pneumatic compression has been accepted as a supplemental therapy for many years. However, due to the diversity of the clinical view of venous lymphedema and difficulties in the diagnosis, there is still no uniform and fully reliable treatment algorithm and international consensus.

Aim of the study: To compare the efficacy of pneumatic compression of various pressure for the treatment of lower extremity venous lymphedema in menopausal patients.

Material and methods: The study included 33 patients with chronic venous insufficiency and bilateral primary lymphedema of the lower limbs. Group A consisted of 10 patients aged from 46 to 56 years (mean age 51.2 years) who had used monthly therapy, treatments consisting of manual lymphatic drainage, multi-layer bandaging and intermittent pneumatic compression with a pressure of $120 \mathrm{~mm} \mathrm{Hg}$. Group B consisted of 10 patients aged from 45 to 58 years (mean age 53.3 years) who had identical basic treatment as group A, and intermittent pneumatic compression with a pressure of $60 \mathrm{~mm} \mathrm{Hg}$. Group C (control) consisted of 13 patients aged from 44 to 57 years (mean age 52.8 years) who were using only primary treatment without intermittent pneumatic compression.

Results: It was found out that the greatest reduction in edema in patients undergoing compression settings with a pressure of $120 \mathrm{~mm} \mathrm{Hg}$. Comparison of the percentage reduction in edema showed a statistically significant advantage for group A to groups B and C, both for changes in the right $(p=0.01)$ and left limb $(p=0.01)$. Results in patients undergoing intermittent pneumatic compression with a lower pressure $(60 \mathrm{~mm} \mathrm{Hg})$ were similar to those obtained in the control group.

Conclusions: Intermittent pneumatic compression with a pressure of $120 \mathrm{~mm} \mathrm{Hg}$ significantly helps to reduce the venous lymphedema in patients with menopause. It appears that the procedures with a pressure of $60 \mathrm{~mm} \mathrm{Hg}$ are ineffective.

Key words: intermittent pneumatic compression, venous lymphedema, menopause.

\section{Streszczenie}

Wstęp: Pierwotny obrzęk chłonny oraz przewlekła niewydolność żylna stanowią istotny problem leczniczy u kobiet w okresie menopauzalnym. Wciąż poszukuje się skutecznych fizykalnych metod terapeutycznych. 
Cel pracy: Porównanie skuteczności sekwencyjnego masażu uciskowego o różnym ciśnieniu w leczeniu pierwotnego obrzęku żylno-chłonnego kończyn dolnych u pacjentek w okresie menopauzalnym.

Materiał i metody: Do badania włączono 33 pacjentki z przewlekłą niewydolnością żylną oraz z obustronnym pierwotnym obrzękiem chłonnym kończyn dolnych. Grupę A stanowiło 10 chorych w wieku 46-56 lat (średni wiek 51,2 roku), u których zastosowano miesięczną terapię przeciwobrzękową składającą się z zabiegów manualnego drenażu limfatycznego, kompresjoterapii oraz sekwencyjnego masażu uciskowego o ciśnieniu wyjściowym 120 mm Hg. Grupę B stanowiło 10 chorych w wieku 45-58 lat (średni wiek 53,3 roku), które poddano identycznemu leczeniu podstawowemu jak w grupie A oraz sekwencyjnemu masażowi uciskowemu o ciśnieniu wyjściowym $60 \mathrm{~mm} \mathrm{Hg.} \mathrm{Grupę} \mathrm{C} \mathrm{(kontrolna)} \mathrm{stanowiło} 13$ chorych w wieku 44-57 lat (średni wiek 52,8 roku), u których zastosowano jedynie terapię podstawową - bez sekwencyjnego masażu uciskowego.

Wyniki: Stwierdzono, że największe zmniejszenie obrzęku miało miejsce u chorych poddanych zabiegom sekwencyjnego masażu uciskowego o ciśnieniu 120 mm Hg. Porównanie procentowej redukcji obrzęku wykazato znamienną statystycznie przewagę grupy A w stosunku do grup B i C zarówno dla zmian w kończynie prawej $(p=0,01)$, jak i lewej $(p=0,01)$. Rezultaty u pacjentek poddanych sekwencyjnemu masażowi uciskowemu o niższym ciśnieniu (60 $\mathrm{mm} \mathrm{Hg}$ ) były zbliżone do uzyskanych w grupie kontrolnej.

Wnioski: Sekwencyjny masaż uciskowy o ciśnieniu zewnętrznym $120 \mathrm{~mm} \mathrm{Hg}$ istotnie wspomaga redukcję obrzęku żylno-chłonnego u chorych w okresie menopauzalnym. Wydaje się, że zabiegi o ciśnieniu $60 \mathrm{~mm} \mathrm{Hg} \mathrm{są}$ nieskuteczne w terapii przeciwobrzękowej u pacjentek z przewlekłą niewydolnością żylną.

Słowa kluczowe: sekwencyjny masaż uciskowy, obrzęk żylno-chłonny, menopauza.

\section{Introduction}

Lymphedema is an abnormal accumulation of stagnant protein-rich fluid in the interstitial matrices of the limbs. The high concentration of protein causes the colloid osmotic pressure to increase, which accelerates fluid transfer into the interstitial space. Lymphedema may be present in the extremities, trunk, abdomen, head and neck, external genitalia, and inner organs. Lymphedema of the lower limbs, which occurs in patients with chronic venous insufficiency is a result of circulatory tissue fluid, lymph and venous blood disorders in the extremity. Patients with venous lymphedema may experience pain, swelling, tightness and heaviness in the affected area, reduction in motion in joints and the documented side effects include cosmetic and functional problems, cellulitis, and other infections, as well as lymphangiosarcoma [1, 2].

The results of most studies show a much higher morbidity associated with the primary lower extremity venous lymphedema among women than men. Previous observations [3-5] indicate a possible effect of hormonal contraception and pregnancy on the emergence of symptoms of chronic venous insufficiency in women, including in the form of edema.

According to some reports it is concluded that the incidence of venous insufficiency among women is about three times higher than in men in the same age range (pregnancy leads to an increase in the risk even four-six times). In addition, it is believed that the number of documented cases of lymphedema of lower limbs in women is about 6 million (4.6 million from the age group of $40-60$ years), of which $60 \%$ of patients have chronic venous insufficiency $[5,6]$.

Decongestive lymphatic therapy is a common management for venous lymphedema. A program combining skin care, manual lymphatic drainage, exercise, and compression therapy (multilayer bandage or garment) is recognized as the best practice in management. Taking into consideration personal and medical resources in clinical practices, intermittent pneumatic compression as a supplemental therapy is often given to patients to improve the effectiveness of lymphatic therapy. It is a mechanical method of delivering compression to swollen limbs. Pneumatic compression has been accepted as a standard supplemental therapy for many years. However, due to the diversity of the clinical views of venous lymphedema and difficulties in diagnosis, there is still no uniform and fully reliable treatment algorithm and international consensus. For example, some authors recommend pressure from 40 to $60 \mathrm{~mm}$ $\mathrm{Hg}[7,8]$ for pneumatic compression, others suggest much higher values from 80 to $130 \mathrm{~mm} \mathrm{Hg}[9,10]$. This fact significantly impedes the treatment process in use of this method.

The aim of the study was to compare the efficacy of intermittent pneumatic compression of various pressure for the treatment of lower extremity venous lymphedema in menopausal patients. The study endpoints were to determine the difference in limb volume before and after therapy in each group and comparison of changes between all groups.

\section{Material and methods}

This study was approved by the Research Ethics Committee of the Medical University of Silesia in Katowice, Poland (protocol number NN/6501/101/06). The present study was done at the Limf-Med Clinics in Chorzow, Poland, and was carried out from September 2009 to July 2012.

Participating subjects met the following inclusion criteria: 1) women, 2) gave written informed consent 
to participate in the study, 3) chronic venous insufficiency and 4) bilateral primary lower limb lymphedema. They were women in menopause, who on the basis of the interview have had time signs of menopause for more than 2 years. Participants have not had menstruations for at least a year. All subjects were non-smokers. Women could not use solarium for six months preceding the study. Patients who qualified to the study due to the venous lymphedema and thromboembolic complications risk, did not use the hormone replacement therapy. The exclusion criteria were: 1) an ankle brachial pressure index (ABPI) lower than 0.8, 2) diabetes, 3) cancer, 4) peripheral nerve injury, 5) rheumatoid arthritis, 6) ventricular arrhythmia, 7) cardiac pacemaker, 8) skin infection, 9) after steroid therapy, and 10) after vein surgery. The 11) secondary lymphedema, 12) pulmonary edema and 13) congestive heart failure, 14) chronic renal failure were exclusion criteria in our protocol, too.

In total, 33 women were included in this study. Participants were randomly allocated to three groups $A, B$ and $C$.

Group A consisted of 10 patients aged from 46 to 56 years (mean age 51.2 years) who had used monthly therapy, treatments consisting of manual lymphatic drainage, multilayer bandaging and intermittent pneumatic compression with a pressure of $120 \mathrm{~mm} \mathrm{Hg}$.

Group B consisted of 10 patients aged from 45 to 58 years (mean age 53.3 years) who had identical basic treatment group $A$, and intermittent pneumatic compression with a pressure of $60 \mathrm{~mm} \mathrm{Hg}$.

Group C (control) consisted of 13 patients aged from 44 to 57 years (mean age 52.8 years) who were using only primary treatment, without intermittent pneumatic compression.

All women were treated in outpatient clinics, where for a period of 4 weeks they had comprehensive physical therapy (manual lymphatic drainage, multilayer bandaging) and standard drug therapy (micronized purified flavonoid fraction $450 \mathrm{mg}$ diosmin, $50 \mathrm{mg}$ hesperidin, 2 tablets of $500 \mathrm{mg}$ once daily). Manual lymphatic drainage was applied by a therapist to develop the central

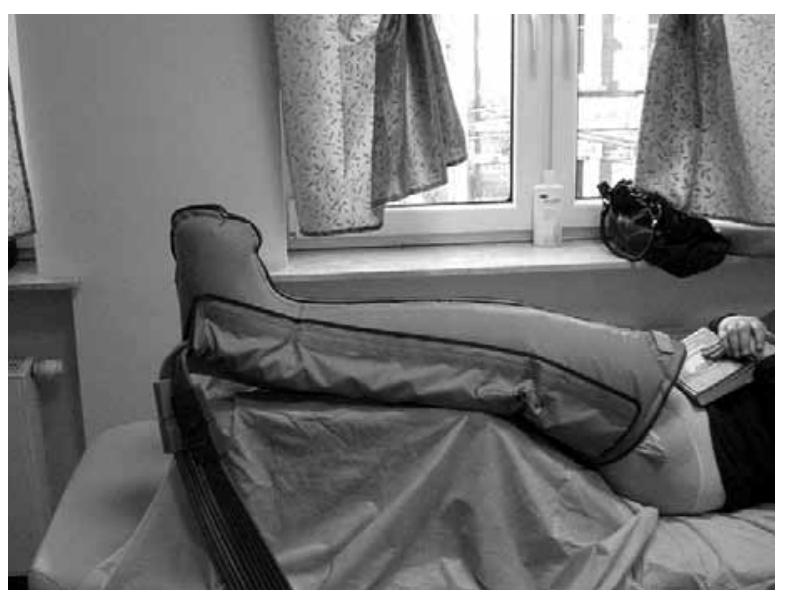

Fig. 1. Intermittent pneumatic compression with 12 chambers techniques on "venous angles" - in subclavian vein area on chest), referred to the receptaculum chyli and retroperitoneal nodes (combined with exercises of diaphragmatic breathing) and finally the whole drain segmented limbs. The massage lasted for 50 minutes and was performed once a day, 3 times weekly. After the manual lymphatic drainage (before patients stand up and limbs were in a low position) used a multilayer bandaging of external pressure of $40-50 \mathrm{~mm} \mathrm{Hg}$. The first layer was applied to the skin directly with a Tubula orthopedic sleeve. Then, a supporting bandage Matoplast was applied to the toes and on foot. Another layer was cotton RoltaSoft covering the whole limb. The external layer consisted of short-stretch Hartmann bandages, which were applied for 20-24 hours.

Additionally, patients in groups $A$ and $B$ received 12-chamber intermittent pneumatic compression therapy (Fig. 1). The Flowtron Hydroven 12 System device was applied to compress the cuff covers to the foot, lower leg, knee and thigh. Patients were subjected to a pressure of $120 \mathrm{~mm} \mathrm{Hg}$ in group A and $60 \mathrm{~mm} \mathrm{Hg}$ in group B. Ventricular filling time in each chamber was $15 \mathrm{~s}$. A single setting lasted for $45 \mathrm{~min}$; during treatment patients were lying. The treatment was performed once a day, 3 times a week (every other day).

To assess the volume of limb, an optoelectronic Perometer $400 \mathrm{~T}$, co-operating with a personal computer was used. This method allowed us to estimate the measuring error as only $0.5 \%$. The assessment technique was based on a special ring, equipped with a system of 378 LED diodes (emitting the infrared radiation). Within the ring there were also optical sensors that receive electromagnetic stimuli. In the course of measuring, the limb was located inside the ring on the diodesensor lines. The registered light pulses on the detectors were turned into electronic signals. The ring was moved during measurement to cover the entire lower limb (Fig. 2). Measurements of the limb volume were made for all three groups of patients before and after therapy.

The $\chi^{2}$ independence test (greatest reliability level) and non-parametric Kruskal Wallis one-way analysis, which is an element of a module of the analysis of variance, were used for comparing indicators, which characterized patients in all comparative groups. Outcome measurements were compared between the groups using Kruskal Wallis analysis of variance and within the groups - using non-parametric Wilcoxon signed-rank test. Two-sided " $p$ " (level of significance) values of less than 0.05 were considered to be statistically significant.

\section{Results}

The participant demographics assessed before randomization are shown in Tables I and II. All groups were homogenous as regards initial edema size and other factors that characterize the patients $(p>0.05)$. 
The average volume of the right lower limb in women from group $A$ (pneumatic compression with a pressure of $120 \mathrm{~mm} \mathrm{Hg}$ ) was $18034.11 \mathrm{~cm}^{3}$, and decreased after treatment to $10051.15 \mathrm{~cm}^{3}(p=0.00001)$. The average volume of the lower extremity was $18008.21 \mathrm{~cm}^{3}$ before, and significantly reduced to $10124.02 \mathrm{~cm}^{3}$ after one month's therapy ( $p=0.00001)$.

The average volume of the right lower limb in women from group $B$ (procedures with a pressure of $60 \mathrm{~mm}$ $\mathrm{Hg}$ ) was $17921.33 \mathrm{~cm}^{3}$, and decreased after treatment to $14641.02 \mathrm{~cm}^{3}(p=0.0002)$. The average volume of the lower extremity was $17890.97 \mathrm{~cm}^{3}$ before, and $14570.76 \mathrm{~cm}^{3}$ after a month's therapy ( $\left.p=0.0002\right)$.

In turn, the average volume of the right lower limb in women from group C (control group) was $17908.41 \mathrm{~cm}^{3}$, and after treatment $15021.22 \mathrm{~cm}^{3}(p=0.0002)$. The average volume of the lower extremity was $17789.99 \mathrm{~cm}^{3}$ before, and decreased to $14789.06 \mathrm{~cm}^{3}$ after a month's therapy ( $p=0.0002)$.

In the study we observed the most significant decrease in edema in patients undergoing compression settings with a pressure of $120 \mathrm{~mm} \mathrm{Hg}$. The comparison of the percentage reduction in edema showed a statistically significant advantage for group $A$ to groups $B$ and $C$, both for changes in the right $(p=0.01)$ and left $\operatorname{limb}(p=0.01)$. Results for patients undergoing intermittent pneumatic compression with a lower pressure $(60 \mathrm{~mm} \mathrm{Hg}$ ) were similar to those obtained in the con-

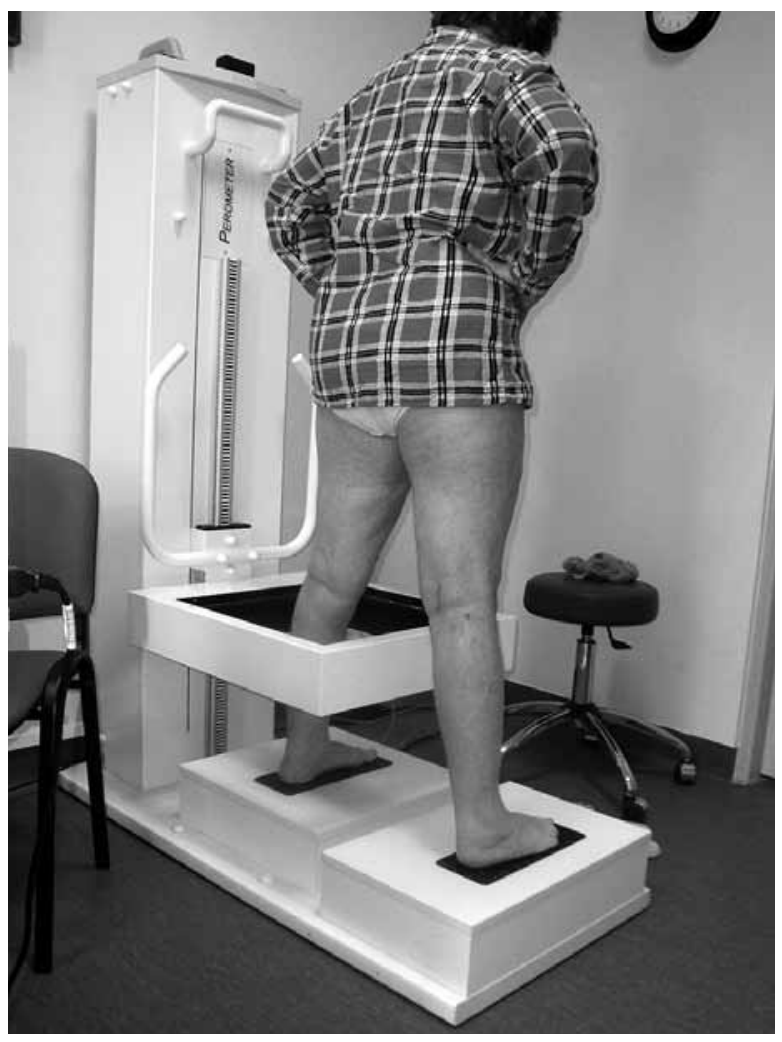

Fig. 2. Optoelectronic ring and perometer trol group (Tables III and IV).

Table I. Characteristics of women in comparative groups

\begin{tabular}{|c|c|c|c|c|c|}
\hline Parameter & & Group A & Group B & Group C & Level of significance $p$ \\
\hline number of patients & & 10 & 10 & 13 & $>0.05$ \\
\hline \multirow{3}{*}{ age (years) } & average & 51.2 & 53.3 & 52.8 & \multirow{3}{*}{$>0.05$} \\
\hline & $\min -\max$ & $46-56$ & $45-58$ & $44-57$ & \\
\hline & SD & 4.2 & 5.3 & 4.1 & \\
\hline \multirow{3}{*}{ BMI $\left(\mathrm{kg} / \mathrm{m}^{2}\right)$} & average & 31.2 & 30.4 & 30.1 & \multirow{3}{*}{$>0.05$} \\
\hline & $\min -\max$ & $24.2-34.2$ & $22.5-32.8$ & $24.8-32.9$ & \\
\hline & SD & 6.2 & 5.9 & 6.1 & \\
\hline \multirow{3}{*}{ duration of disorder (years) } & average & 11.2 & 10.6 & 9.8 & \multirow{3}{*}{$>0.05$} \\
\hline & $\min -\max$ & $2.2-17.1$ & $2.5-13.3$ & $4.8-15.4$ & \\
\hline & SD & 9.8 & 7.9 & 7.1 & \\
\hline \multirow{3}{*}{ initial edema $\left(\mathrm{cm}^{3}\right)$} & average & 18034.1 & 17921.3 & 17908.4 & \multirow{3}{*}{$>0.05$} \\
\hline & $\min -\max$ & $2022.2-1598.1$ & $22033.5-14431.3$ & $24005.1-14402.4$ & \\
\hline & SD & 5679.8 & 70072.2 & 90093.1 & \\
\hline \multirow{3}{*}{$\begin{array}{l}\text { edema stage by Olszewski } \\
\text { classification* (number of patients) } \\
\text { R-right leg, L-left leg }\end{array}$} & Ila & $3 R / 3 L$ & $3 R / 3 L$ & $5 \mathrm{R} / 4 \mathrm{~L}$ & \multirow{3}{*}{$>0.05$} \\
\hline & IVa & $5 \mathrm{R} / 4 \mathrm{~L}$ & $4 \mathrm{R} / 4 \mathrm{~L}$ & $4 \mathrm{R} / 5 \mathrm{~L}$ & \\
\hline & IVc & $2 R / 2 L$ & $3 R / 3 L$ & $4 \mathrm{R} / 4 \mathrm{~L}$ & \\
\hline
\end{tabular}

"stage Ila (soft, plastic edema of the foot and crural area), stage IVa (soft, plastic edema of the whole leg), stage IVc (edema with dermatitis, lymphadenitis, tissue fibrosis of the whole leg) 
Table II. Characteristics of chronic venous insufficiency

\begin{tabular}{|c|c|c|c|c|}
\hline $\begin{array}{l}\text { Scale CEAP* (number } \\
\text { of patients) R-right } \\
\text { leg, L-left leg }\end{array}$ & $\begin{array}{c}\text { Group } \\
\text { A }\end{array}$ & $\begin{array}{c}\text { Group } \\
\text { B }\end{array}$ & $\underset{C}{\text { Group }}$ & $\begin{array}{l}\text { Level of } \\
\text { signifi- } \\
\text { cance } p\end{array}$ \\
\hline$C_{3} E_{p} A_{S 2,3} P_{R}$ & & $6 \mathrm{R} / 7 \mathrm{~L}$ & $7 \mathrm{R} / 7 \mathrm{~L}$ & $>0.05$ \\
\hline$C_{4} E_{p} A_{S 2 D 13} P_{R}$ & $2 \mathrm{R} / 2 \mathrm{~L}$ & $2 \mathrm{R} / 2 \mathrm{~L}$ & $4 \mathrm{R} / 4 \mathrm{~L}$ & $>0.05$ \\
\hline $\mathrm{C}_{4} \mathrm{E}_{\mathrm{P}} \mathrm{A}_{52,3 \mathrm{D} 13,14 \mathrm{P} 18} \mathrm{P}_{\mathrm{R}}$ & $2 \mathrm{R} / 1 \mathrm{~L}$ & $2 \mathrm{R} / 1 \mathrm{~L}$ & $2 \mathrm{R} / 2 \mathrm{~L}$ & $>0.05$ \\
\hline \multicolumn{5}{|c|}{$\begin{array}{l}{ }^{*} C_{3} E_{P} A_{S 2,3} P_{R} \text { (edema, primary etiology, venous reflux in upper and lower } \\
\text { segments of the greater saphenous vein), } C_{4} E_{p} A_{S 2} P_{13} P_{R} \text { (edema, primary } \\
\text { etiology, venous reflux in upper segments of the greater saphenous and } \\
\text { femoral vein), } C_{4} E_{p} A_{S 2,3} A_{13,14 P 18} P_{R} \text { (edema, primary etiology, venous reflux in } \\
\text { upper/lower segments of greater saphenous, popliteal and femoral veins, } \\
\text { saphenofemoral and saphenopopliteal junctions) }\end{array}$} \\
\hline
\end{tabular}

\section{Discussion}

The intermittent pneumatic compression has been suggested as a promising treatment option for acute (post-operative, post-burn) edema, chronic venous insufficiency, cellulite and chronic disorders like venous or lymphatic ones, but there are still many controversies connected with pressure values.

Olszewski [9] maintains that lymphatics contract rhythmically with a frequency depending on the volume of inflowing tissue fluid. In regions with a high capillary filtration rate and tissue fluid formation, the frequency is high. The recorded pressures at rest, irrespective of whether in the lying or upright position, with free proximal flow (lateral pressure) range between 7 and $30 \mathrm{~mm} \mathrm{Hg}$ and during foot flexing between 10 and $30 \mathrm{~mm} \mathrm{Hg}$. The pulse amplitude is 3 to $20 \mathrm{~mm} \mathrm{Hg}$ and 5 to $17 \mathrm{~mm} \mathrm{Hg}$, respectively. The pulse frequency is 0.6 to $6 / \mathrm{min}$ and 2 to $8 / \mathrm{min}$, respectively. The resting end pressures with obstructed flow (e.g. corresponding to lymphatic obstruction in postsurgical lymphedema or in primary venous lymphedema) range between 15 and $55 \mathrm{~mm} \mathrm{Hg}$ and during foot flexing 15 to $50 \mathrm{~mm} \mathrm{Hg}$. The pulse amplitude is 3 to $35 \mathrm{~mm} \mathrm{Hg}$ and 3 to $14 \mathrm{~mm} \mathrm{Hg}$, respectively. The pulse frequency is 2.5 to $10 / \mathrm{min}$ and 3 to $12 / \mathrm{min}$, respectively.

It means that the external low pressure value during pneumatic compression procedures (under $80 \mathrm{~mm}$ $\mathrm{Hg}$ ) has no effect on lymph pressures. In obstructive lymphedema, only few lymphatic collectors remain patent. The recorded pressures during rest range from 5 to $45 \mathrm{~mm} \mathrm{Hg}$ depending on the remaining contractility force of the damaged lymphatic musculature. During calf muscular contractions, pressures are generally low ranging from 10 to $25 \mathrm{~mm} \mathrm{Hg}$, although well-conducted intermittent compression may in some cases generate pressures of above $200 \mathrm{~mm} \mathrm{Hg}$. The author [9] recommends only high pressure range: $100-160 \mathrm{~mm} \mathrm{Hg}$ and time: $40-60$ minutes. In his opinion, lower values are useless, which is similar to our view of the results arising from the study.

However, Ponikowska et al. [7] argue that the pressure range of the pneumatic compression must not
Table III. Comparison a percentage change in edema between groups (right leg)

\begin{tabular}{lccc}
\hline & Group A & Group B & Group C \\
\hline Average $(\%)$ & 46.23 & 20.03 & 18.46 \\
\hline SD $(\%)$ & 12.13 & 7.09 & 6.76 \\
\hline$p(A$ vs. $B)=0.01 ; p(A$ vs. $C)=0.01 ; p(B$ vs. $C)>0.05$ &
\end{tabular}

Table IV. Comparison a percentage change in edema between groups (left leg)

\begin{tabular}{lccc}
\hline & Group A & Group B & Group C \\
\hline Average (\%) & 44.58 & 19.77 & 17.89 \\
\hline SD (\%) & 10.57 & 8.07 & 6.89 \\
\hline
\end{tabular}

$p(A$ vs. $B)=0.01 ; p(A$ vs. $C)=0.01 ; p(B$ vs. $C)>0.05$

exceed 40-50 mm Hg, as higher performance may result in damage to the lymphatic vessels, and have adverse consequences on the damaged venous valves in the forms of lymphedema in patients with venous insufficiency, and may not be well tolerated by excessive pressure on the pain receptors in the skin. The researchers noticed the decrease in the limb volume from 9231 $\mathrm{cm}^{3}$ to $7490 \mathrm{~cm}^{3}(p=0.024)$ after three weeks' therapy (5 procedures, once daily from Monday to Friday). A single procedure lasted for 30 minutes. The weakness of this study was lack of the control (placebo) group and much smaller edema sizes compared to our study.

Similar recommendations were also presented by Woźniewski and Kolodziej [8], explaining that the higher pressure in the pneumatic compression therapy than $60 \mathrm{~mm} \mathrm{Hg}$ should not be applied to patients with venous lymphedema, because higher parameters can be painful and damage the skin vessels (lymphatic precollectors in the skin circulatory system). These authors applied the external pressure of $50 \mathrm{~mm} \mathrm{Hg}$ in $10 \mathrm{pa}$ tients during one month's treatment, but also without control groups and comparing to other pressure values. The mean volume decreased by about $10 \%(p=0.034)$. For example, in our control group (without intermittent pneumatic compression), the edema was reduced by about $12-15 \%$. It means that it is extremely difficult to conclude about the efficacy of pneumatic compression procedures without estimation the placebo effect.

The additional problem in venous lymphedema of menopausal patients is pain feelings and quality of life [9-15]. In our study, the external pressure of $60 \mathrm{~mm} \mathrm{Hg}$ did not reduce in a significant way venous lymphedema of the lower limbs. In the group of patients with $120 \mathrm{~mm} \mathrm{Hg}$, we noticed a significant reduction. Moreover, high pressure was well tolerated by patients and did not cause discomfort and pain.

In recent literature (Pubmed, Medline, PEDro), we have found only one article and Szolnoky et al. [16] recruited 38 menopausal women with lipedema to 
the study with 19 patients undergoing treatment and 19 serving as a control group using exclusively moisturizers. Treatment consisted of once daily manual lymph drainage (MLD), intermittent pneumatic compression, and multilayered short-stretch bandaging performed throughout a 5-day-course. Pain was evaluated with a 10-item questionnaire, a pain rating scale (PRS), and the Wong-Baker Faces scale. Treatment resulted in a significant reduction in pain with a decrease in mean scores of all three measures. In the control group, only PRS showed a significant decrease. The study results indicated that this treatment regimen not only reduces leg volume and capillary fragility, but also improves pain intensity in patients with lipedema.

Also, Taiwan researchers [17] included in their study thirty-one patients with infrapopliteal diffuse or multiple segmental lesions. Based on receipt of intermittent pneumatic therapy (3 hours daily for 3 months), patients were allocated to a study $(n=23)$ or control $(n=8)$ groups. The 6-minute walking test, transcutaneous oxygen tension $\left(\mathrm{TCPO}_{2}\right)$, and quality of life (QOL) evaluated with the Short-Form 36 questionnaire were measured at the beginning and end of the study. In the QOL analysis, scores for physical functioning, physical and emotional role functioning, bodily pain, and general and mental health showed significant changes after pneumatic compression therapy. In the 6-minute walking test, duration, and the initial and absolute claudication distances were significantly increased in the study group. The $\mathrm{TCPO}_{2}$ was also significantly increased in the distal end of the target limb after therapy. Authors concluded that patients at a high risk of amputation with infrapopliteal diffuse or multiple segmental lesions can improve their walking ability, $\mathrm{TcPO}_{2}$ of the target limb and QOL after intermittent compression therapy.

In the literature there are no randomized controlled studies with menopause patients and venous lymphedema. We will continue our study. To date we have analyzed only a pilot group of menopausal patients with primary lymphedema and chronic venous insufficiency, further studies will be provided.

\section{Conclusions}

The intermittent pneumatic compression with a pressure of $120 \mathrm{~mm} \mathrm{Hg}$ significantly helps to reduce the venous lymphatic edema in patients with menopause. It appears that the procedures with a pressure of $60 \mathrm{~mm} \mathrm{Hg}$ are ineffective.

\section{References}

1. Ruciński A, Janczak D, Szyber P. Results of complex lower limb lymphoedema therapy. Pol Surg Rev 2002; 74: 430-5.

2. Kompresjoterapia - przewodnik praktyczny dla fizjoterapeutów i pielęgniarek. Kucharzewski M, Taradaj J, Halski T (eds.). Continuo, Wrocław 2012.

3. Krasiński Z, Kotwicka M, Dzieciuchowicz $九$, et al. Varicose veins of women - role of sex hormones. Przegl Gin Poł 2005; 5: 315-21.

4. Canonico M, Plu-Bureau G, Lowe GD, Scarabin PY. Hormone replacement therapy and risk of venous thromboembolism in postmenopausal women: systematic review and meta-analysis. BMJ 2008; 336: 1227-31.

5. Gabriel M, Pawlaczyk K, Krasiński Z, Dzieciuchowicz Ł. Venous insufficiency in postmenopausal women. Prz Menopauz 2011; 15: 279-83.

6. Szyber P, Szyber P. Lymphedema - therapeutic problem. Therapy 2008; 2: $70-2$.

7. Ponikowska I, Górczyńska K, Szczepanowski A. Intermittent pneumatic compression therapy in lower leg venous - lymphatic disorders. Acta Balneol 1997; 39: 87-93.

8. Woźniewski M, Kołodziej J. Rehabilitacja w chirurgii. Wydawnictwo Lekarskie PZWL, Warszawa, 2006

9. Olszewski WL The "third" circulation in human limbs-tissue fluid, lymph and lymphatics. Phlebologie 2012; 41: 297-303.

10. Taradaj J, Halski T, Pilok K, et al. The evaluation of the impact of complex anti - edema therapy on even reduction of upper limb lymphedema after breast amputation. Lecz Ran 2009; 6, 1: 15-8.

11. Barnas E, Krupińska A, Krasnianin E, Ras E. Psychosocial and occupational functioning of women in menopause. Prz Menopauz 2012; 16: 296-304.

12. Dabrowska J, Naworska B, Dabrowska-Galas M, Skrzypulec-Plinta V. The role of physical activity in menopause. Prz Menopauz 2012; 16: 445-8.

13. Tolwińska A, Kisielewski R, Laudański P. Chronic pelvic pain in menopausal women. Prz Menopauz 2012; 16: 187-91.

14. Walczak A, Wisniewska B. Psychosocial aspects of functioning of women in postmenopausal period: a preliminary study. Prz Menopauz 2012; 16: 474-7.

15. Wozniak P, Ziolkowski P, Stetkiewicz T, et al. Is acupuncture effective in treatment of hot flashes? Prz Menopauz 2012; 16: 319-23

16. Szolnoky G, Varga E, Varga M, et al. Lymphedema treatment decreases pain intensity in lipedema. Lymphology 201; 4: 178-82.

17. Chang ST, Hsu JT, Chu CM, et al. Using intermittent pneumatic compression therapy to improve quality of life for symptomatic patients with infrapopliteal diffuse peripheral obstructive disease. Circ J 2012; 4: 971-6. 